\title{
Utilization of Artocarpus heterophylla Lamk. as UV Protector in mice exposed to UV-B
}

\author{
Ketut Agus Adrianta*, I Made Agus Sunadi Putra \\ Akademi Farmasi Saraswati, Denpasar, Bali, Indonesia
}

\begin{abstract}
In daily life, Artocarpus heterophylla Lamk., the leaves are rarely used even just as animal feed. In the bark of Artocarpus heterophylla Lamk there are new flavonoid compounds namely morusin, artokarpin, artonin E, cycloartobilosantone, and artonol B. This research is an experimental design with randomized posttest only with control group design. A total of 21 mice were divided into 3 groups, each consisting of 7 mice, group 1: negative control given oral placebo and exposed to UV-B rays, group 2:giving Vitamin C cream 4\% mg and exposed to UV-B rays, group 3: giving cream of Artocarpus heterophylla Lamk leaf extract 4\% and exposed to UV-B rays. The total of UV radiation dose of $600 \mathrm{~mJ} / \mathrm{cm}^{2}$ for 3 weeks, then performed a biopsy for examination of the amount of dermis collagen. The average number of collagen in the three groups after treatment was given significantly different $(\mathrm{p}<0.05)$. Mean and Significant level of collagen density of group $1: 51,42 \pm 5,16$; group P2 $\pm 91,18 \pm 1,13$; and P3 group: 88,77 $\pm 1,10$. Conclusion : Cream of $4 \%$ Artocarpus heterophylla Lamk leaf extract can increase the amount of collagen density in mice exposed to UV-B rays.
\end{abstract}

Key words: Artocarpus heterophylla Lamk; artokarpin; uv-protector; collagen

\section{INTRODUCTION}

UV light exposure in addition to providing beneficial effects to help the formation of vitamin D required by the bone, but also has an adverse effect. These effects depend on the intensity of the sun, the frequency of irradiation, the duration of irradiation, and the exposed surface area of sun exposure (Hadinoto et al., 2000). Overall, the effects of UV radiation on the dermis result in collagen degradation, collagen synthesis barriers, inflammation and oxidative stress, as well as decreased cell capability and eventually apoptosis. Various research has been done by experts to prove that the increase of UV-B radiation in the earth resulted in an increase in cases of skin cancer. For example, WHO estimates that in 2008 worldwide there are about 2 million new cases every year for nonmelanoma skin cancer, while melanoma skin cancer is about 132,000 new cases each year. In Indonesia, skin cancer patients are fewer than the United States, Australia and Britain, but skin cancer needs to be avoided because in addition to causing disability (damaging appearance) also at an advanced stage can be fatal for the patient. One way that can be done to reduce the negative impact of sunlight, namely by using sunscreen. According to Permenkes RI number 376 / menkes / per / VIII / 1990, sunscreen is a substance that can absorb at least $85 \%$ of sunlight

\section{*Corresponding author : Ketut Agus Adrianta} Email : agusaick@gmail.com at wavelengths of 290 to $320 \mathrm{~nm}$ but can continue the light at wavelengths greater than $320 \mathrm{~nm}$. The effectiveness of sunscreen preparation in resisting exposure to sunlight and heat is influenced by the stability of the active ingredient and the stability of the sunscreen preparation.

The development of skin protective cream from UV rays to the use of natural materials has become a trend because it is more easily accepted by the community. This is due to the assumption that the use of natural materials (herbs) is safer to use and has relatively little negative impact. The use of herbs as a medicine is a cultural heritage based on skills, knowledge and experiences passed down from generation to generation by previous generations.

One of the herbs that can be used is jackfruit leaf (Artocarpus heterophylla Lamk.). In life, Artocarpus heterophylla Lamk plants, especially on the leaves are rarely used even just as animal feed. In the bark of Artocarpus heterophylla Lamk there are new flavonoid compounds, namely morusin, artokarpin, artonin E, cycloartobilosantone, and artonol B (Ersam, 2001). Artokarpin result of wood isolation on Artocarpus heterophylla Lamk also has potent activity as whitening agent and anticancer skin (Arung et al., 2008).

\section{METHODOLOGY}

This research is an experimental research using Randomize Post Test Only With Control Group Design. 


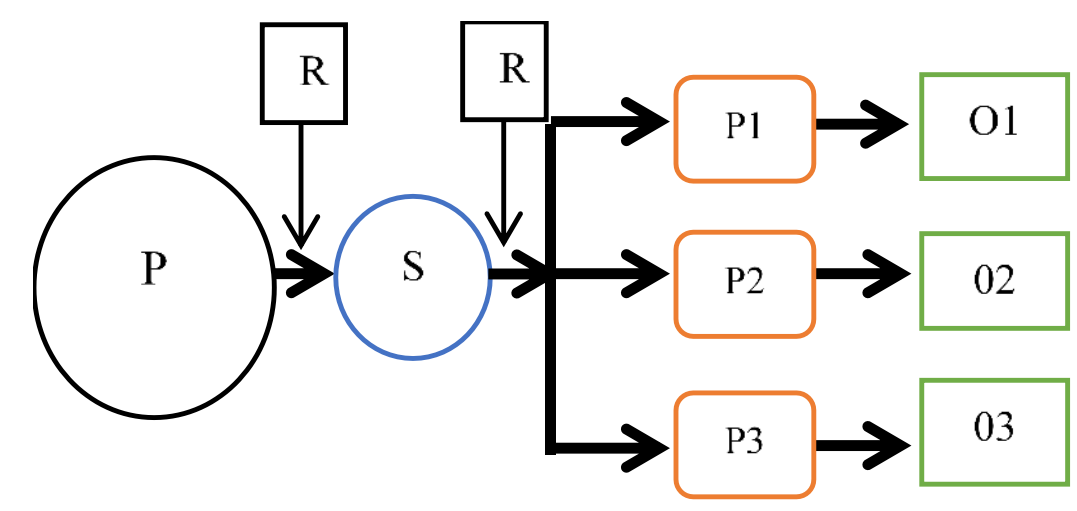

Figure 1. Research design

P : Population; S : Sample; R : Random; P1 : Placebo; P2 : Positive Control; P3 : heterophylla Lamk extract cream

\section{Artocarpus heterophylla Lamk simplisia preparation}

Generally simplicia making through the following stages: collection of raw materials, washing, chopping, drying, drying, packing and storage.

\section{Preparing the Artocarpu heterophylla Lamk extract}

The Artocarpus heterophylla Lamk leaf ethanol extract was prepared by using ethanol solvent, then macerated with magnetic stirer until the sample sample was colorless and the filtrate was evaporated with a temperature evaporator of $40^{\circ} \mathrm{C}$ until a concentrated sample (ethanol extract) was obtained.

\section{Preparation of Extract Ethanol Leaf cream 4\%}

\begin{tabular}{lc}
\hline \multicolumn{1}{c}{ Ingredients } & Base Formulation (\%) \\
\hline Stearic acid & 3 \\
Setil alcohol & 4 \\
Propylene glycol & - \\
Glycerine & 2 \\
Trietanolamin & - \\
Cera alba & 1 \\
Liq. Parafin & 6 \\
Tween 80 & 3 \\
Methyl paraben & 0,1 \\
Phospat buffer pH & 100 \\
7,4 ad & \\
\hline
\end{tabular}

The cream base in this research is the type of oil emulsion in water (M /A). In each formula, the oil phase is melted in a vapor plate above the waterbath at $\pm 75^{\circ} \mathrm{C}$ (first mixture), and the water phase is dissolved in phosphate buffer $\mathrm{pH} 7.4 \pm$
75으 $\mathrm{C}$ (second mixture). The two mixtures are stirred on a hot, homogeneous mortar and form a cream mass. Added methyl paraben and glycerin bit by bit while crushed to homogeneous.

\section{Research procedure}

Implementation of research through the following stages:

1. A total of 21 mice were adapted for 1 week.

2. Randomly, mice were divided into groups. control group, group 1, group 2, and group 3

3. Mice of all groups shaved back feathers, then smeared cream base ingredients in the control group, 4\% Vitamin C cream in group 2, cream ethanol extract of $4 \%$ Artocarpus heterophylla Lamk leaves in group 3, each cream smeared $0.2 \mathrm{mg} / \mathrm{cm} 2$ surface of mice leather.

4. Chronic exposure of UV-B was given to the control group, group 2, group 3. Exposure was done 3 times a week (Monday, Wednesday and Friday) for 3 weeks with exposure of $50 \mathrm{~mJ} /$ $\mathrm{cm} 2$ in the first week, with exposure of $70 \mathrm{~mJ} /$ $\mathrm{cm} 2$ at week second, and with an exposure of $80 \mathrm{~mJ} / \mathrm{cm} 2$ in the third week.

5. The basic ingredients of cream, $4 \%$ Vitamin C cream, 4\% Artocarpus heterophylla Lamk ethanol extract cream were applied twice daily, about 20 minutes before exposure (to give absorption time of topical material into the skin) and 4 hours after irradiation. Topical application of the material remains on a day without irradiation.

6. 48 hours after the last irradiation, to exclude the effects of acute irradiation, all mice from all three groups were rested for 48 hours after the last irradiation. After that euthanasia and then taken back skin tissue, inserted in $40 \%$ 


\section{Group I : Placebo}

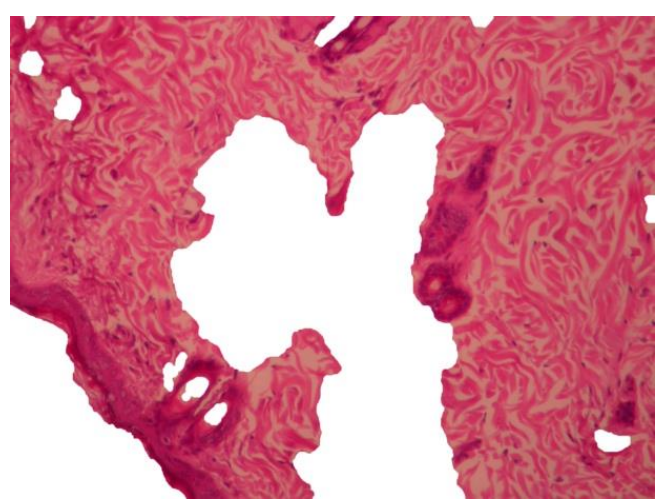

Figure 2. Collagen Density : 50,79\%

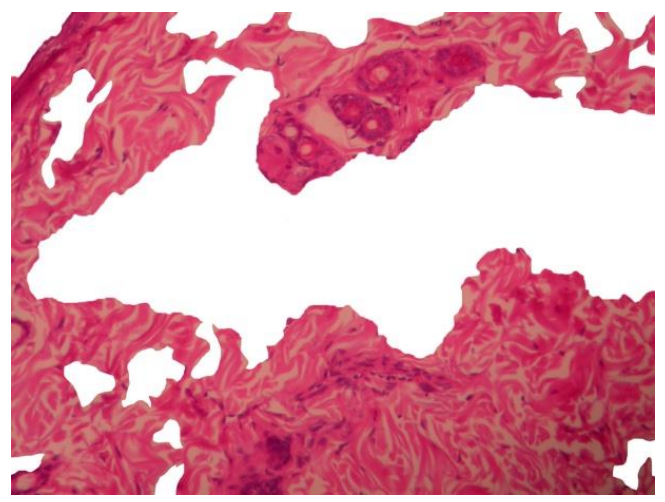

Figure 4. Collagen Density : 45,13\%

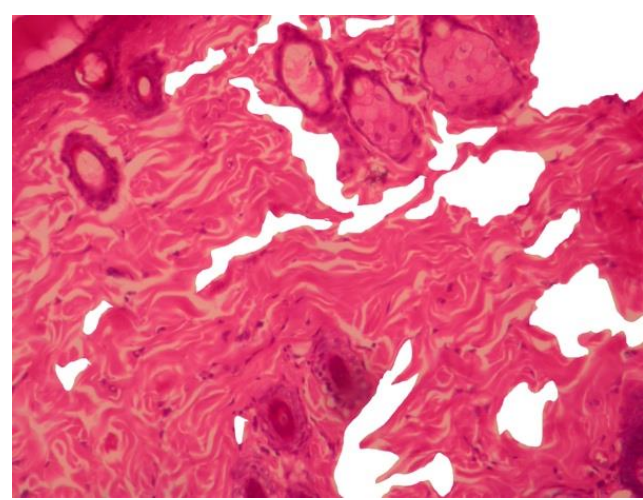

Figure 3. Collagen Density : 51,16\%

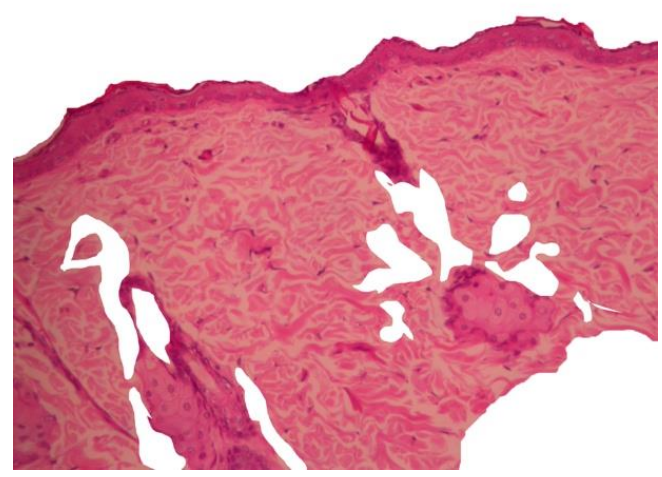

Figure 5. Collagen Density : 46,75\%

Table I. Collagen Density Artocarpus heterophylla Lamk

\begin{tabular}{cccc}
\hline No & Placebo & Positive Group Vitamin C 4\% & Jackfruit leaf cream extract 4\% \\
\hline 1 & 50.79 & 91.11 & 90.12 \\
2 & 51.16 & 93.85 & 87.60 \\
3 & 45.13 & 91.55 & 87.81 \\
4 & 46.75 & 91.56 & 88.93 \\
5 & 52.83 & 89.01 & 88.16 \\
6 & 52.15 & 91.10 & 89.97 \\
7 & 61.19 & 91.17 & 90.19 \\
Mean & $51,42 \pm 5.16$ & $91.18 \pm 1,13$ & $88.77 \pm 1.10$ \\
\pm SD & & & \\
\hline
\end{tabular}

formalin solution. Skin tissue mice made histologic preparations for examination of skin collagen count.

\section{RESULTS AND DISCUSSION \\ Collagen Histopatological}

All test animals in each group were analyzed immunohistochemically, to see the collagen density.

The results of the statistical analysis were started with the normality test showing that the treatment of Group 1 (Plasebo) was 0.094 (p> 0.05), while for treatment Group 2 (positive control) and group 3 (Treatment of extract) were 0.330 and $0.323(p>0.05)$. The test results state that all data is normally distributed.

The average number of collagen cells between the negative control group (P1) the positive control group (Vit C 4\%) (P2) was significantly different with the $\mathrm{p}$ value $=0.000$, indicating that there was a difference in collagen density between the negative control group and 


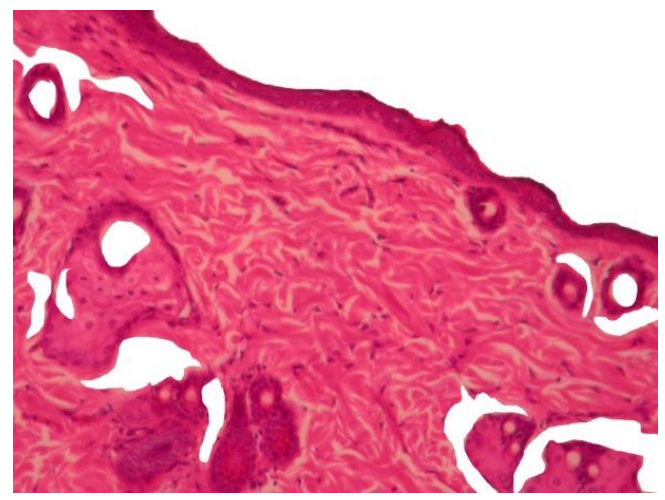

Figure 6. Collagen Density : 52,15\%

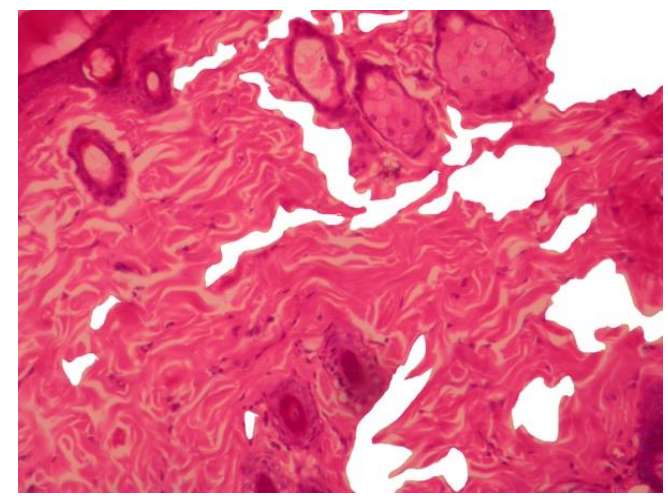

Figure 7. Collagen Density : 52,15\%

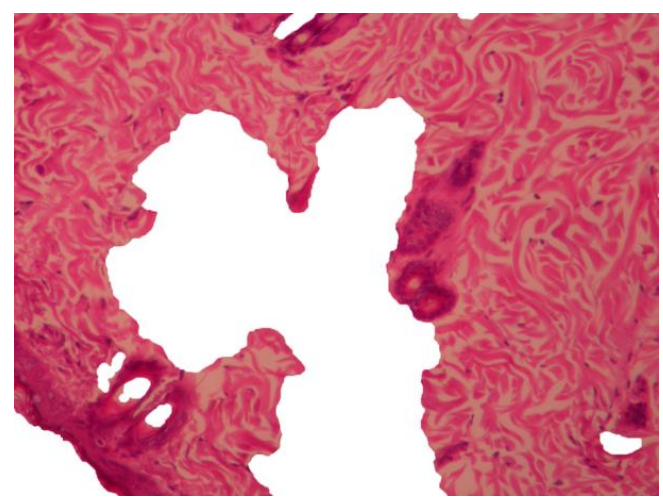

Figure 8. Collagen Density : 46,75\%

\section{Group 2 : Positive Control ( Cream With 4\% As.Ascorbic)}

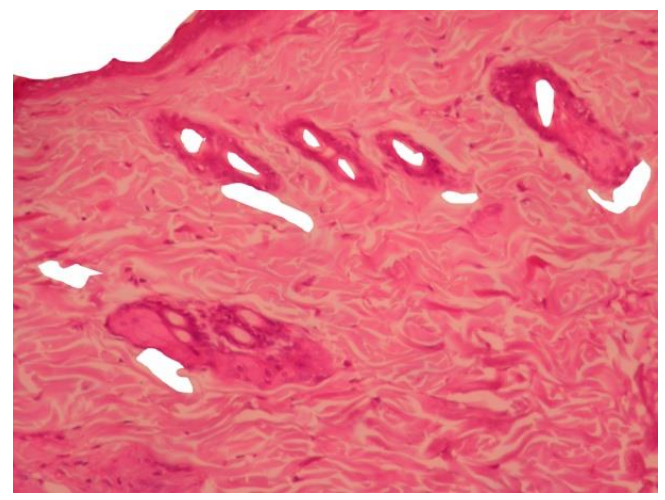

Figure 9.Collagen Density : 91,11\%

the administration of vitamin C. Group 2 (P2) of vitamin $C$ has a greater density. The mean number of collagen cells between the placebo group (P1) and the group of 4\% leaf extract (P3) significantly differed with $\mathrm{p}=0,000$, indicating that there was a difference of collagen density between the negative control group and the administration group Extract cream jackfruit leaves 4\%. Visible Group of extract of cream of jackfruit leaves 4\% have bigger density. The average number of collagen cells between the positive control group (P2) and the 4\% jackfruit collecting group (P3) did

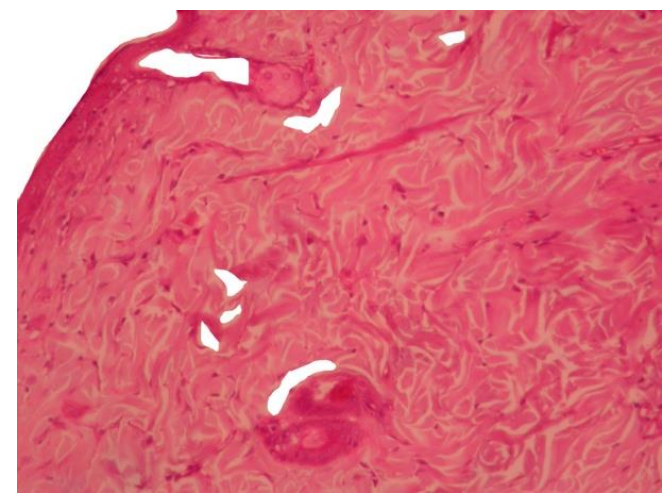

Figure 10.Collagen Density : 93,85\%

not differ significantly with $\mathrm{p}=0.175$. Indicates that both groups give the same density results.

Excessive UV exposure, in addition to reducing the amount of mature collagen in the dermis, also destroy the synthesis of collagen in a sustainable manner. Cream Artocarpus heterophylla Lamk. contribute secondary metabolites in the form of: morin, sianomaklurin (tannic), flavonoids, and tannins. In addition, in the bark also contain new flavonoid compounds, namely morusin, artonin E, artokarpin, sikloartobilosanton, and artonol B. 


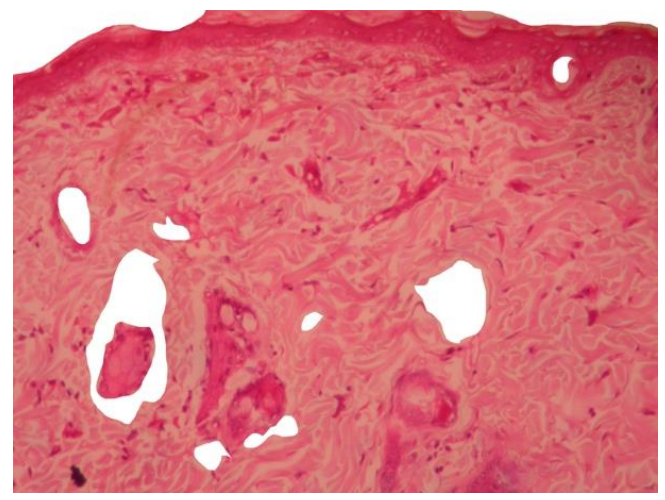

Figure 11.Collagen Density : 91,55\%

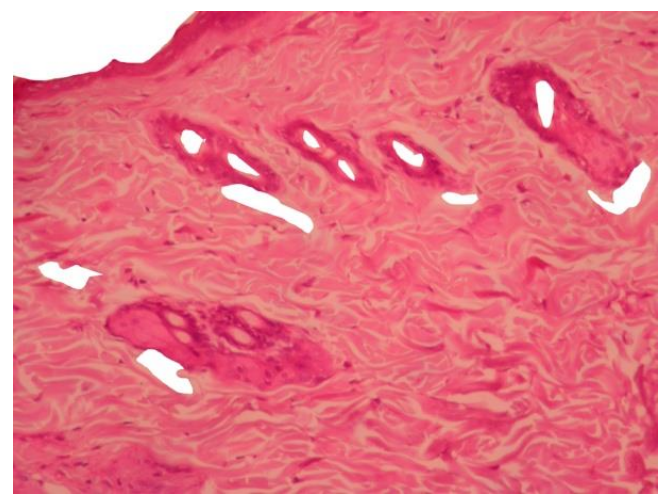

Figure 13.Collagen Density : 89,01\%

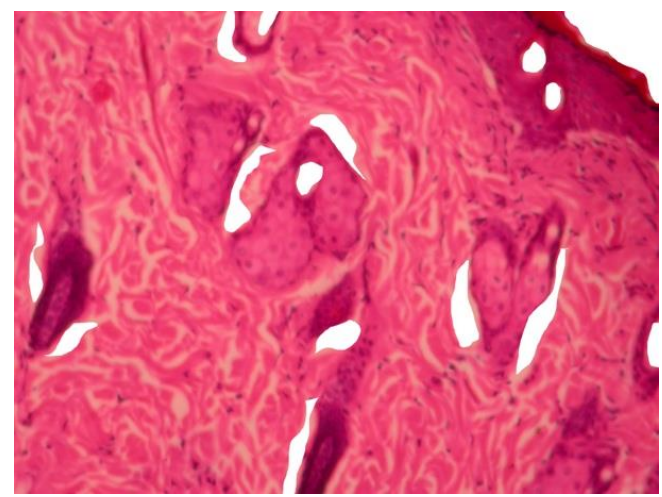

Figure 12.Collagen Density : 91,56 \%

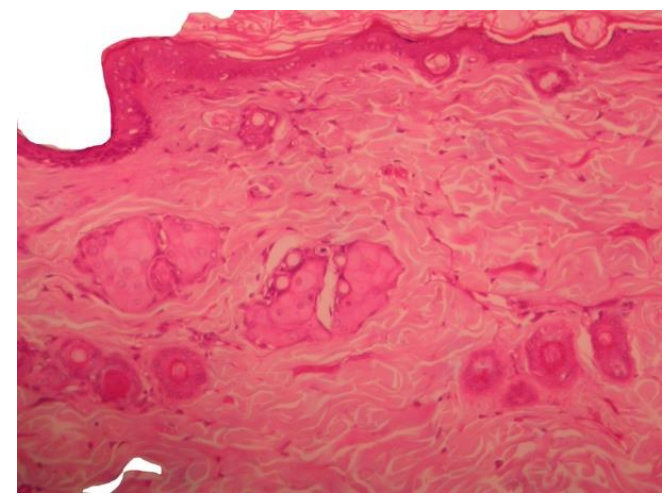

Figure 14.Collagen Density : 91,10

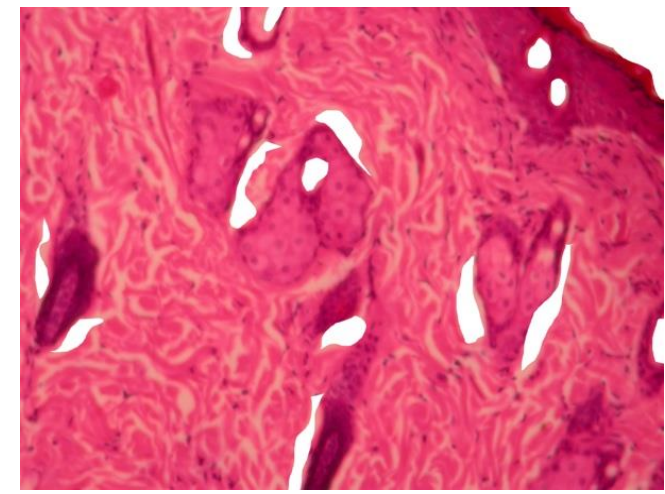

Figure 15.Collagen Density : 91,56 \%

UV-B exposure in experimental animals will cause damage to collagen tissue characterized by decreased concentration of collagen density. Flavonoids contained Cream Artocarpus heterophylla Lamk. extract containing morin, cyanomaclurin (tannin), flavonoids, and tannins have a role as UV-Protector by inhibiting exposure to UV rays so that no reduction in the amount of mature collagen in the dermis, Flavonoid also allegedly able to protect the synthesis collagen continuously, so there is no decrease in regulation of procollagen gene expression of type I and type
III. Two mechanisms are responsible for the reduced expression of the procollagen gene so that 4\% Artocarpus heterophylla Lamk. leaf extract is able to maintain the production of collagen.

\section{CONCLUSION}

From the results of this study can be concluded that the gift of jackfruit leaf extract $4 \%$ can be used as an alternative as UV protective. Artocarpus heterophylla Lamk leaf extract $4 \%$ statistically has average density level which is not significantly different compared with Vitamin $\mathrm{C}$ as 


\section{Group 3 : Cream With 4\% Artocarpus heterophylla Lamk}

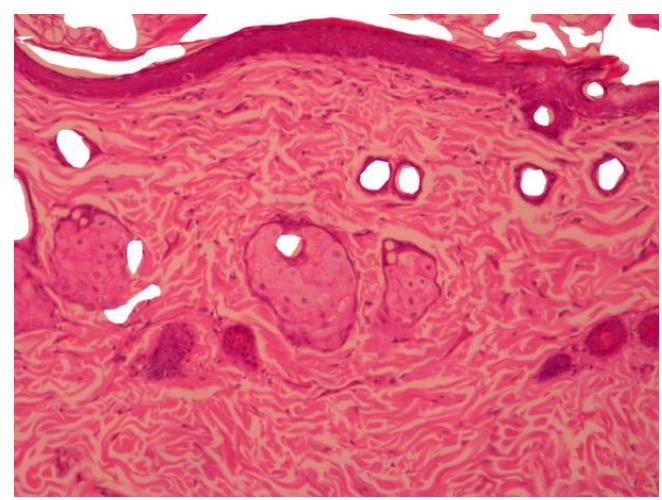

Figure 16.Collagen Density : 90,12\%

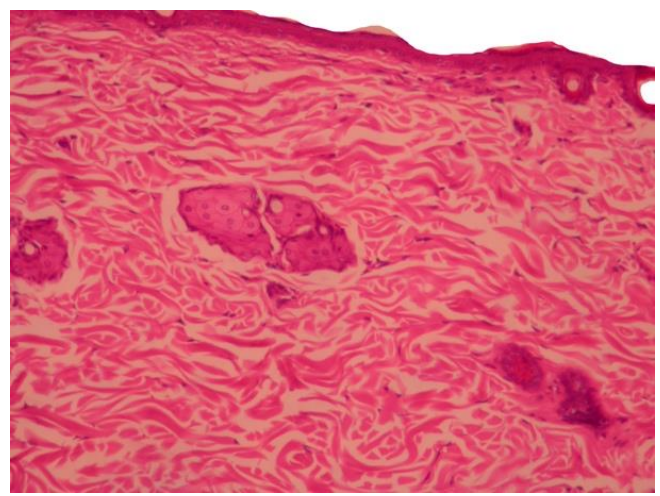

Figure 18.Collagen Density : 87,81

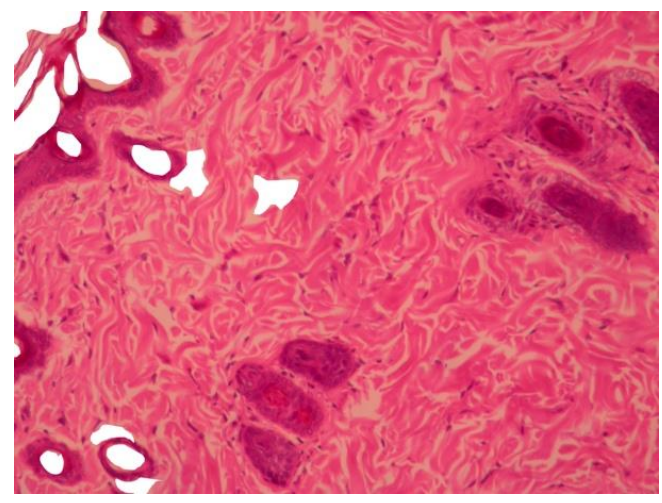

Figure 20.Collagen Density : 88,16\%

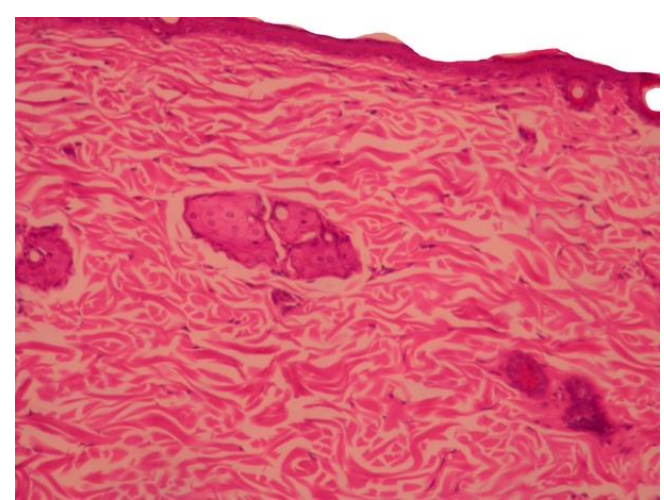

Figure 17.Collagen Density : 87,60\%

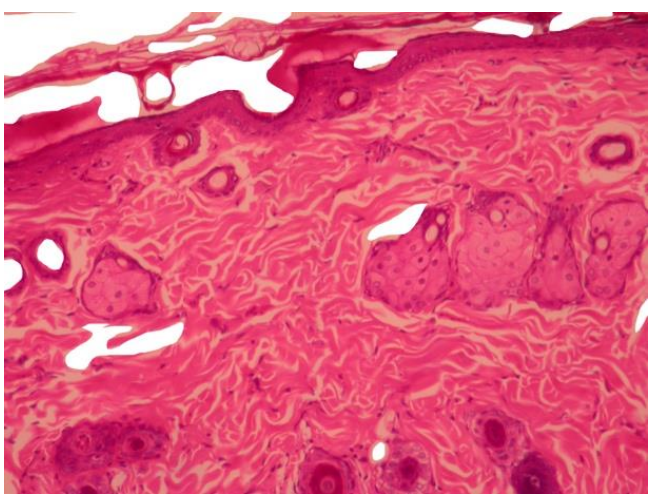

Figure 19.Collagen Density : 88.93\%

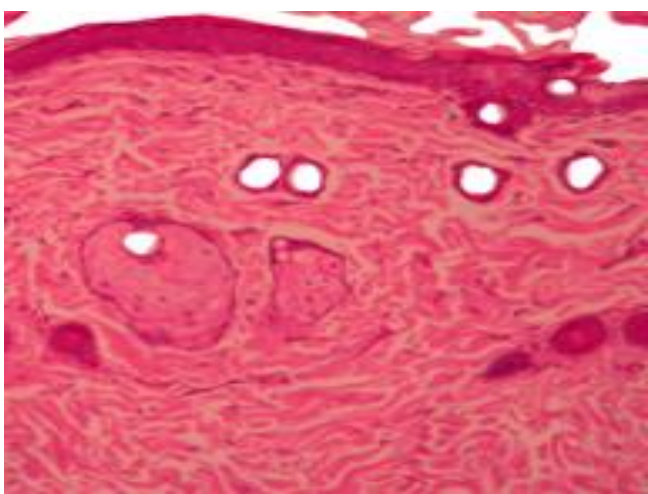

Figure 21.Collagen Density : 89,97\%

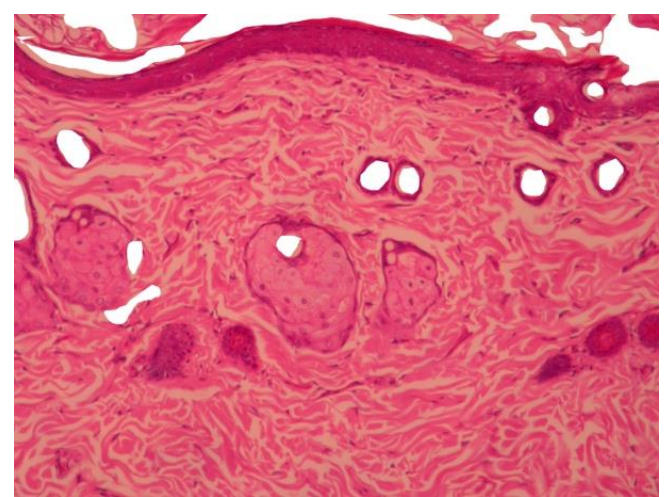

Figure 22.Collagen Density : 90,19\% 
Table II. Statistical analysis of comparism collagen density between group

\begin{tabular}{ccc}
\hline Group & Group Refference & p Value \\
\hline P1 & P2 & 0,000 \\
& P3 & 0,000 \\
P2 & P1 & 0,000 \\
& P3 & 0,175 \\
P3 & P1 & 0,000 \\
& P2 & 0,175 \\
\hline
\end{tabular}

positive control. And it can be said that the use of jackfruit leaf extract has the same effectiveness as vitamin $\mathrm{C}$ as uv-protection.

\section{ACKNOWLEDGEMENTS}

I would like to thank the parties who helped carry out this research. Thanks to Direktorat Riset dan Pengabdian Masyarakat, Direktorat Jenderal Penguatan Riset dan Pengembangan Kementerian Riset, Teknologi dan Pendidikan Tinggi who has funded this research.

\section{REFERENCES}

Almatsier, Sunita. 2004. Prinsip Dasar Ilmu Gizi. Jakarta : PT. Gramedia Pustaka Utama.

Ersam, T. 2001. Senyawa Kimia Makromolekul Beberapa Tumbuhan Artocarpus HutanTropika Sumatera Barat, (Disertasi). Bandung : ITB.

Federer, W. T. 2011. Statistical Design and Analysis for Intercropping Experiments. New York : Springer. p 30-33.

Fisher, G. J., Kang S., Varani, J., Bata-Csorgo, Z., Wan, Y., Datta, S., and Voorhees, J. J. 2002. Mechanisms of Photoaging and Chronological Skin Aging. Arch Dermatology. 138:1462-70.

Gonzaga, E.R. 2009. Role of UV Light in Photodamage, Skin Aging, and Skin Cancer. Importance of Photoprotection. Am J Clin Dermatol. 10 (1): 19-24.

Helfrich, Y.R., Sachs, D. L., and Voorhees, J. J. 2009. The Biology of Skin Ageing. European Dermatology. 39-42.

Kadler, K. E., Holmes, D. F., Trotter, J. A., \& Chapman, J. A. 1996. No Title Collagen fibril formation. Biochemical Journal, 316, 1.

Marczyk., Geoffrey, R., Dematteo, D., Festinger, D.
2005. Experimental design. In: Dematteo, D., David., editors. Essential of Research Design and Methodology. First edition. New Jersey : John-Wiley. p 48-56.

Nichols, J.A., Katiyar, S.K. 2010. Skin Photoprotection by Natural Polyphenols: Antiinflammatory, Anti-oxidant and DNA repair mechanisms. Arch Dermatol Res. 302(2): 71.

Rukmana, R. 1997. Nangka Budidaya dan Pasca panen. Yogyakarta : Kanisius.

Sauermann, K., Jaspers, S., Koop, U., and Wenek, H. 2004. Topically Applied Vitamin C Increases The Density of Dermal Papillae in Aged Human Skin. BMC Dermatology. 4:13.

Scott, D., Bennion, M. S. 2011. Structure and Function of The Skin. In: Fitzpatrick, J. E., Morelli, J. G., editors. Dermatology Secret Plus. Fourth edition. Philadelphia : Elsevier Mosby. P 6-13.

Soeratri, W., Hadinoto, I., \& Anastasia, T. Penentuan Nilai SPF In Vitro Sediaan Krim Tabir Surya Matahari Etilheksil-pmetoksisinamat dan Oksibenson. Majalah Farmasi Airlangga.

Varani, et al., 2001. Inhibition of Type I Procollagen Synthesis by Damage Collagen in Photoaged Skin and by Collagenase-Degraded Collagen in Vitro. The Journal of Pathology. 158(3): 931-42.

Wilkinson, J.B. 1982. Harry's Cosmeticology $7^{\text {th }}$ Edition. London : George Godwin.

Yulia. 2009. Penentuan Komposisi Optimal Kombinasi Sulisobenzon dan Dietilamino Hidroksibenzoil Heksil Benzoat dalam Sediaan Krim Tabir Surya. Bandung : Universitas Jenderal Achmad Yan. 